Research Article

\title{
Chronological Classification of Ancient Mortars Employing Spectroscopy and Spectrometry Techniques: Sagunto (Valencia, Spain) Case
}

\author{
M. Ramacciotti, ${ }^{1,2}$ S. Rubio, ${ }^{2}$ G. Gallello $\mathbb{D}^{1,2,3}$ M. Lezzerini ${ }^{1 D},{ }^{4,5}$ S. Columbu, \\ E. Hernandez, ${ }^{7}$ A. Morales-Rubio, ${ }^{2}$ A. Pastor, ${ }^{2}$ and M. de la Guardia ${ }^{2}$ \\ ${ }^{1}$ Department of Prehistory, Archaeology and Ancient History, Faculty of Geography and History, University of Valencia, \\ Av. Blasco Ibáñez 28, 46010 Valencia, Spain \\ ${ }^{2}$ Department of Analytical Chemistry, Faculty of Chemistry, University of Valencia, C/ Dr. Moliner 50, 46100 Burjassot, \\ Valencia, Spain \\ ${ }^{3}$ Department of Archaeology, University of York, King's Manor, York YO1 7EP, UK \\ ${ }^{4}$ Department of Earth Sciences, University of Pisa, Via S. Maria 53, 56126 Pisa, Italy \\ ${ }^{5}$ Applied and Laser Spectroscopy Laboratory, ICCOM-CNR, Via G. Moruzzi 1, 56124 Pisa, Italy \\ ${ }^{6}$ Department of Chemical and Geological Sciences, University of Cagliari, Via Trentino 51, 09127 Cagliari, Italy \\ ${ }^{7}$ Sagunto Archaeological Museum, C/ del Castillo 23, 46500 Sagunto, Valencia, Spain \\ Correspondence should be addressed to G. Gallello; gianni.gallello@york.ac.uk
}

Received 15 March 2018; Accepted 22 April 2018; Published 9 May 2018

Academic Editor: Javier Garcia-Guinea

Copyright ( 92018 M. Ramacciotti et al. This is an open access article distributed under the Creative Commons Attribution License, which permits unrestricted use, distribution, and reproduction in any medium, provided the original work is properly cited.

\begin{abstract}
Forty-two mortar samples, from two archaeological excavations located in Sagunto (Valencian Community, Spain), were analysed by both portable energy dispersive X-ray fluorescence spectroscopy (pED-XRF) and inductively coupled plasma mass spectrometry (ICP-MS) to determine major and minor elements and traces including rare earth elements (REEs). Collected data were crossed with those previously obtained from Sagunto Castle mortars, and principal component analysis (PCA) was applied to discriminate the construction phases of the unearthed buildings. REE permitted to ascribe most of the masonries to the Roman Imperial period. Moreover, a statistical model was built by employing partial least squares discriminant analysis (PLS-DA) in order to classify the mortars from Roman Imperial period and from Islamic period due to the problematic overlapping between these two phases. Results confirmed the effectiveness of the developed indirect chronology method, based on REE data, to discriminate among historic mortars from different construction periods on a wide scale including different Sagunto archaeological sites.
\end{abstract}

\section{Introduction}

Mortar is a building material composed essentially of binder and aggregate fractions and, in some cases, of additives of different types [1-3]. In particular, lime mortar had a key function in Roman architecture: Roman people made their walls and structures with this material adding reactive materials, like pozzolan materials (i.e., pulvis puteolanus and cocciopesto), to give a hydraulic character to the mortars [4-8]. The use of mortar in architecture is documented during the Middle Ages and in the following historical periods [6-13].

The chemical analysis by statistical approach, together with mineralogical and petrographic characterization of ancient mortars and polished stones, has shown to be a useful tool in the interpretation of the construction phases of several archaeological sites and historical complexes [14-20]. Moreover, ancient mortars are subjected to decay phenomena which also must be detected and evaluated for conservation issues [21-24]. 
TABle 1: Sample description including area and building of sampling sites and mortar type.

\begin{tabular}{|c|c|c|c|}
\hline Sample & $\begin{array}{c}\text { Archaeological } \\
\text { excavation }\end{array}$ & Building & $\begin{array}{c}\text { Mortar } \\
\text { type }\end{array}$ \\
\hline C05 & Los Huertos Street & Circus MSU1005 & $\begin{array}{l}\text { Lime } \\
\text { mortar }\end{array}$ \\
\hline $\mathrm{C} 06$ & Los Huertos Street & Circus MSU1006 & $\begin{array}{l}\text { Lime } \\
\text { mortar }\end{array}$ \\
\hline $\mathrm{C} 07$ & Los Huertos Street & Circus MSU1007 & $\begin{array}{l}\text { Lime } \\
\text { mortar }\end{array}$ \\
\hline C08 & Los Huertos Street & Circus MSU1008 & $\begin{array}{l}\text { Lime } \\
\text { mortar }\end{array}$ \\
\hline C09 & Los Huertos Street & Circus MSU1009 & $\begin{array}{l}\text { Lime } \\
\text { mortar }\end{array}$ \\
\hline $\mathrm{C} 10 \mathrm{a}$ & Los Huertos Street & Circus MSU1010a & $\begin{array}{l}\text { Lime } \\
\text { mortar }\end{array}$ \\
\hline C10b & Los Huertos Street & Circus MSU1010b & $\begin{array}{l}\text { Lime } \\
\text { mortar }\end{array}$ \\
\hline $\mathrm{C} 20$ & Los Huertos Street & Circus MSU1020 & $\begin{array}{l}\text { Lime } \\
\text { mortar }\end{array}$ \\
\hline $\mathrm{C} 26$ & Los Huertos Street & Circus MSU1026 & $\begin{array}{l}\text { Lime } \\
\text { mortar }\end{array}$ \\
\hline CLC & Los Huertos Street & Cloaca & $\begin{array}{l}\text { Lime } \\
\text { mortar }\end{array}$ \\
\hline EW & Los Huertos Street & Eastern Wall & $\begin{array}{l}\text { Lime } \\
\text { mortar }\end{array}$ \\
\hline JMN & Los Huertos Street & Northern Jamb & $\begin{array}{l}\text { Lime } \\
\text { mortar }\end{array}$ \\
\hline NR & Los Huertos Street & Noria & $\begin{array}{l}\text { Lime } \\
\text { mortar }\end{array}$ \\
\hline NW & Los Huertos Street & Northern Wall & $\begin{array}{l}\text { Lime } \\
\text { mortar }\end{array}$ \\
\hline P15 & Los Huertos Street & Pilaster MSU3015 & $\begin{array}{l}\text { Lime } \\
\text { mortar }\end{array}$ \\
\hline P16 & Los Huertos Street & Pilaster MSU3016 & $\begin{array}{l}\text { Lime } \\
\text { mortar }\end{array}$ \\
\hline P17 & Los Huertos Street & Pilaster MSU3017 & $\begin{array}{l}\text { Lime } \\
\text { mortar }\end{array}$ \\
\hline $\mathrm{P} 18$ & Los Huertos Street & Pilaster MSU3018 & $\begin{array}{l}\text { Lime } \\
\text { mortar }\end{array}$ \\
\hline $\mathrm{R} 3 \mathrm{a}$ & Los Huertos Street & Room 3 MSU1032 & $\begin{array}{l}\text { Lime } \\
\text { mortar }\end{array}$ \\
\hline $\mathrm{R} 3 \mathrm{~b}$ & Los Huertos Street & Room 3 MSU1050 & $\begin{array}{l}\text { Lime } \\
\text { mortar }\end{array}$ \\
\hline UN1 & Los Huertos Street & $\begin{array}{l}\text { Unknown } \\
\text { MSU3038 }\end{array}$ & $\begin{array}{l}\text { Lime } \\
\text { mortar }\end{array}$ \\
\hline UN2 & Los Huertos Street & $\begin{array}{l}\text { Unknown } \\
\text { MSU6006 }\end{array}$ & $\begin{array}{l}\text { Lime } \\
\text { mortar }\end{array}$ \\
\hline WLL & Los Huertos Street & Well & $\begin{array}{l}\text { Lime } \\
\text { mortar }\end{array}$ \\
\hline RS10A & Railroad Station & MSU1010a & $\begin{array}{l}\text { Lime } \\
\text { mortar }\end{array}$ \\
\hline RS10B & Railroad Station & MSU1010b & $\begin{array}{l}\text { Lime } \\
\text { mortar }\end{array}$ \\
\hline RS10C & Railroad Station & MSU1010c & $\begin{array}{l}\text { Lime } \\
\text { mortar }\end{array}$ \\
\hline RS11A & Railroad Station & MSU1011a & $\begin{array}{l}\text { Lime } \\
\text { mortar }\end{array}$ \\
\hline RS11B & Railroad Station & MSU1011b & $\begin{array}{l}\text { Lime } \\
\text { mortar }\end{array}$ \\
\hline RS11C & Railroad Station & MSU1011c & $\begin{array}{l}\text { Lime } \\
\text { mortar }\end{array}$ \\
\hline
\end{tabular}

TABle 1: Continued.

\begin{tabular}{|c|c|c|c|}
\hline Sample & $\begin{array}{c}\text { Archaeological } \\
\text { excavation }\end{array}$ & Building & $\begin{array}{c}\text { Mortar } \\
\text { type }\end{array}$ \\
\hline RS24A & Railroad Station & MSU1024a & $\begin{array}{l}\text { Lime } \\
\text { mortar }\end{array}$ \\
\hline RS24B & Railroad Station & MSU1024b & $\begin{array}{l}\text { Lime } \\
\text { mortar }\end{array}$ \\
\hline RS24C & Railroad Station & MSU1024c & $\begin{array}{l}\text { Lime } \\
\text { mortar }\end{array}$ \\
\hline RS25A & Railroad Station & MSU1025a & $\begin{array}{l}\text { Lime } \\
\text { mortar }\end{array}$ \\
\hline RS25B & Railroad Station & MSU1025b & $\begin{array}{l}\text { Lime } \\
\text { mortar }\end{array}$ \\
\hline RS25C & Railroad Station & MSU1025c & $\begin{array}{l}\text { Lime } \\
\text { mortar }\end{array}$ \\
\hline RSLW & Railroad Station & Long Wall & $\begin{array}{l}\text { Lime } \\
\text { mortar }\end{array}$ \\
\hline R1a & Los Huertos Street & Room 1 MSU3029 & $\begin{array}{l}\text { Earth } \\
\text { mortar }\end{array}$ \\
\hline $\mathrm{R} 1 \mathrm{~b}$ & Los Huertos Street & Room 1 MSU3030 & $\begin{array}{l}\text { Earth } \\
\text { mortar }\end{array}$ \\
\hline $\mathrm{R} 1 \mathrm{c}$ & Los Huertos Street & Room 1 MSU3039 & $\begin{array}{l}\text { Earth } \\
\text { mortar }\end{array}$ \\
\hline $\mathrm{R} 2 \mathrm{a}$ & Los Huertos Street & Room 2 MSU3062 & $\begin{array}{l}\text { Earth } \\
\text { mortar }\end{array}$ \\
\hline $\mathrm{R} 2 \mathrm{~b}$ & Los Huertos Street & Room 2 MSU3063 & $\begin{array}{l}\text { Earth } \\
\text { mortar }\end{array}$ \\
\hline $\mathrm{R} 2 \mathrm{~d}$ & Los Huertos Street & Room 2 MSU3064 & $\begin{array}{l}\text { Earth } \\
\text { mortar }\end{array}$ \\
\hline
\end{tabular}

Note. MSU: masonry stratigraphic unit.

This paper shows the results of the analyses carried out on ancient mortars collected from buildings discovered during two recent archaeological excavations at Sagunto, a town located in the Eastern Spain, ca. $30 \mathrm{~km}$ north of Valencia, close to the Costa del Azahar on the Mediterranean Sea. Sagunto is well known in the world for its complex history, and its area has been occupied since the Iberian Age. During the Roman period, Sagunto was interested in constructing important buildings such as the Circus and the Theatre. Thereafter, Sagunto was occupied by Islamic people, and during the Modern Ages, the city was involved in the Napoleonic Wars [25].

The collected mortar samples were analysed by both portable energy dispersive X-ray fluorescence spectroscopy (pED-XRF) and by an inductively coupled plasma mass spectrometer (ICP-MS) to determine their major elements, minor elements, and trace elements. The mineral element concentration and, in particular, the measured contents of rare earth elements (REE) of these samples were compared with those previously obtained from Sagunto Castle [26] by applying principal component analysis (PCA) and partial least squares discriminant analysis (PLS-DA) to determine the construction periods.

\section{Materials and Methods}

2.1. Sampling. The studied mortars (Table 1) were sampled during two archaeological excavations located in the city of 


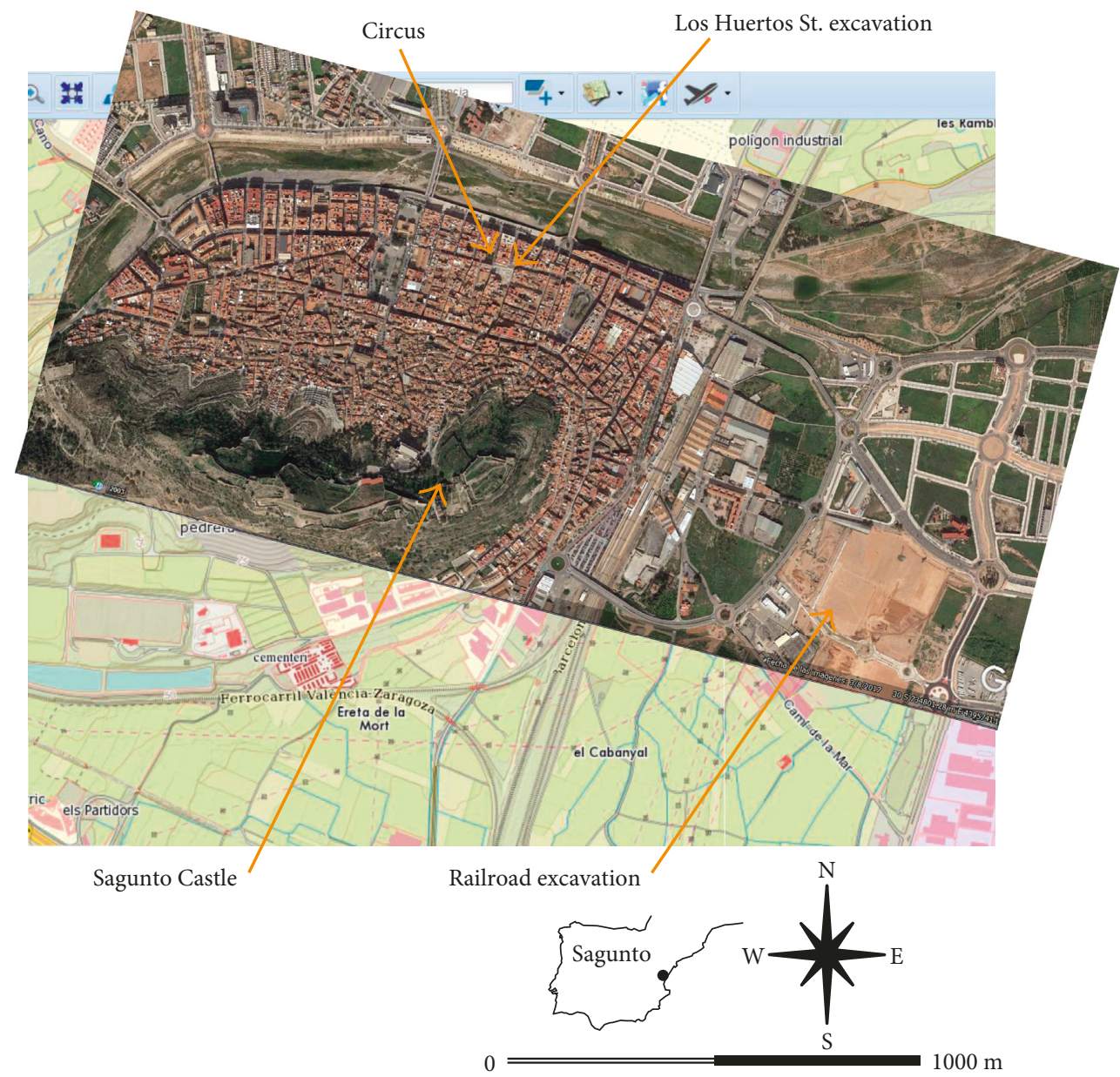

FIGURE 1: Map of the city of Sagunto with the area of sampling (the satellite picture was obtained from Google Earth while the map of Sagunto from the Institut Cartogràfic Valencià, http://www.icv.gva.es).

Sagunto (Figure 1). Twenty-nine samples were collected during the archaeological excavation of Los Huertos St., an area characterized by the presence of buildings and materials from the Roman Imperial phase and from the Islamic occupation in the Middle Ages. Twenty-three samples of lime mortars were collected from these buildings: nine samples come from the Circus (C), a building dating back to the Roman Imperial period, one from the cloaca (CLC), one from a jamb (JMN), two from two different walls (Eastern Wall, EW, and Northern Wall, NW), one from a noria (NR), and four from a pilaster (P). Six samples of earth mortar come from two rooms that the archaeologists interpreted as may belong to the Islamic occupation (Room 1, samples R1 and Room 2, samples R2), and in this study, they were analysed as control samples. Two samples of lime mortar were collected from Room 3 (R3), two from an unidentified building (UN), and one from a well (WLL). Thirteen samples of lime mortars were collected from different masonries during the emergency archaeological excavation of an area close to Sagunto's Railroad Station (RS named samples). Data of twenty-three lime mortar samples from different buildings of the Castle of Sagunto, studied by Gallello et al. [26], were taken into account as the calibration set to perform data analysis and to date the structures of the above- quoted excavations. Part of the calibration samples come from masonries dating back to the Roman Imperial Period: five samples from the Theatre (TR) and one from the Curia (CUR); the other samples come from masonries dated back to the Islamic occupation phase: four samples from the first part of the Islamic Wall (MI), one of the wall which was considered modern before the study (MM), one from a Hermitage (ERM), two from two Islamic reworks of the Torre Central Estudiantes (TCE), and two from the tabernae of the Imperial Forum. Moreover, two samples from the Curia (CUR) and five samples from the Basilica of the Imperial Forum (FBI), whose dating was uncertain between the above-quoted two phases, were added to the dataset.

2.2. Major and Minor Elements Determination. All the analyses were carried out on each entire mortar sample previously pulverized $\left(D_{\max }<63 \mu \mathrm{m}\right)$ and homogenized through Agatha mortar and pestle. Major and minor element concentrations were obtained by using a S1 Titan energy dispersive portable X-ray fluorescence spectrometer (pED-XRF) from Bruker (Kennewick, Washington DC, USA) equipped with an Rh X-ray tube and X-Flash ${ }^{\circledR}$ SDD. Geochem-trace calibration was used to perform the quantitative analyses, and 
TABLE 2: Accuracy of pED-XRF analysis evaluated through the use of CRM (soil NIM GBW07408 and limestone NCS DC60108a) reference samples. As regards NCS DC60108a, not detected Ti concentration and uncertainty of $\mathrm{Al}_{2} \mathrm{O}_{3}$ determination in the limestone sample are related to the sensitivity of the spectrometer.

\begin{tabular}{lcccc}
\hline \multirow{2}{*}{ Element } & \multicolumn{2}{c}{ NIM GBW07408 } & \multicolumn{2}{c}{ NCS DC60108a } \\
& Certified & Measured & Certified & Measured \\
\hline $\mathrm{Al}_{2} \mathrm{O}_{3}$ & $11.92 \pm 0.15$ & $12.06 \pm 0.81$ & $0.33 \pm 0.03$ & $0.61 \pm 0.19$ \\
$\mathrm{SiO}_{2}$ & $58.61 \pm 0.13$ & $52.87 \pm 3.71$ & $2.09 \pm 0.06$ & $2.76 \pm 0.05$ \\
$\mathrm{CaO}$ & $8.27 \pm 0.12$ & $8.60 \pm 0.28$ & $51.61 \pm 0.15$ & $50.31 \pm 3.15$ \\
$\mathrm{Ti}$ & $0.38 \pm 0.01$ & $0.37 \pm 0.01$ & $0.009 \pm 0.001$ & N/D \\
$\mathrm{Fe}$ & $3.13 \pm 0.03$ & $3.27 \pm 0.09$ & $0.12 \pm 0.02$ & $0.15 \pm 0.01$ \\
\hline
\end{tabular}

Note. Certified and measured values of the analyzed elements. The values are expressed as weight percentages (wt.\%). N/D: not detected.

TABLE 3: ICP-MS parameters employed for the mineral analysis.

\begin{tabular}{lc}
\hline Instrumental conditions & \\
Vacuum pressure (Pa) & $5.8 \times 10^{-6}$ \\
Flow of plasma gas Ar (L/min) & 1.0 \\
RF power (W) & 1550 \\
RF coupling (V) & 1.80 \\
Sampling depth (mm) & 8.0 \\
Nebulizer pump (rps) & 0.3 \\
\hline Lens & \\
Extraction lens 1 (V) & 0 \\
Extraction lens 2 (V) & -200 \\
Omega lens (V) & 9.2 \\
Omega lens deviation (V) & -120 \\
\hline Sample parameters & 0.35 \\
Carrier flow (L/min) & $\mathrm{HI}-8$ \\
Work mode & \\
\hline Integration parameters & Spectrum \\
Acquisition mode & 1 \\
Per peak points & 3 \\
Replicates & 100 \\
Per replicas' readings & $0.5-1$ \\
Dwell time UMA (s)
\end{tabular}

S1 Sync software from Bruker was employed to measure $\mathrm{Al}_{2} \mathrm{O}_{3}, \mathrm{SiO}_{2}, \mathrm{CaO}, \mathrm{Ti}$, and $\mathrm{Fe}$. The accuracy of the measurements was verified by using the following certified reference materials: soil NIM GBW07408 and limestone NCS DC60108a (Table 2). All the reading's standard errors range between 1 and 5 wt.\%, except for $\mathrm{Al}_{2} \mathrm{O}_{3}$ measured on NCS DC60108a, whose standard deviation increases up to $22 \mathrm{wt} \%$ for concentration less than $0.5 \mathrm{wt}$. $\%$ probably due to the low sensitivity of the instrument for the determination of this element.

2.3. Trace Elements and REE Determination. Previously pulverized and homogenized samples of each entire mortar were prepared for the inductively coupled plasma mass spectrometry (ICP-MS) analysis. The mortars digestion method was developed by Gallello et al. [26] in order to provide reproducible and comparable results compatible with the sensitivity of the analytical method employed. The wet digestion consisted in the addition of $1.35 \mathrm{~mL}$ of $\mathrm{HCl}$ (37\%) and $0.45 \mathrm{~mL}$ of $\mathrm{HNO}_{3}(69 \%)$ to ca. $0.15 \mathrm{~g}$ of each
TABLE 4: Analytical features of mineral elements determination in mortar samples by ICP-MS.

\begin{tabular}{|c|c|c|c|c|}
\hline Element & Mass & LOD & LOQ & $R^{2}$ \\
\hline$\overline{\mathrm{La}}$ & 139 & 0.0009 & 0.003 & 0.9994 \\
\hline $\mathrm{Ce}$ & 140 & 0.0009 & 0.003 & 0.9993 \\
\hline $\operatorname{Pr}$ & 141 & 0.0003 & 0.0010 & 0.9991 \\
\hline $\mathrm{Nd}$ & 142 & 0.002 & 0.007 & 0.9994 \\
\hline $\mathrm{Sm}$ & 152 & 0.0002 & 0.0007 & 0.9992 \\
\hline $\mathrm{Eu}$ & 151 & 0.0005 & 0.0017 & 0.9998 \\
\hline $\mathrm{Gd}$ & 158 & 0.004 & 0.015 & 0.9993 \\
\hline $\mathrm{Tb}$ & 159 & 0.00011 & 0.0004 & 0.9989 \\
\hline Dy & 162 & 0.0007 & 0.002 & 0.9991 \\
\hline Ho & 165 & 7.4E-05 & 0.0002 & 0.9991 \\
\hline Er & 166 & 0.0003 & 0.0011 & 0.9989 \\
\hline $\mathrm{Tm}$ & 169 & 0.00017 & 0.0006 & 0.9986 \\
\hline $\mathrm{Yb}$ & 172 & 0.0006 & 0.002 & 0.9989 \\
\hline $\mathrm{Lu}$ & 175 & 0.00015 & 0.0005 & 0.9990 \\
\hline Sc & 45 & 0.02 & 0.08 & 0.9999 \\
\hline Y & 89 & 0.0013 & 0.004 & 0.9999 \\
\hline $\mathrm{Ba}$ & 138 & 0.002 & 0.008 & 0.9992 \\
\hline $\mathrm{Bi}$ & 209 & 0.006 & 0.018 & 0.9991 \\
\hline $\mathrm{Cd}$ & 111 & 0.003 & 0.011 & 0.9998 \\
\hline $\mathrm{Cr}$ & 52 & 0.4 & 1.3 & 0.9999 \\
\hline Co & 59 & 0.008 & 0.03 & 0.9998 \\
\hline $\mathrm{Cu}$ & 63 & 0.009 & 0.03 & 0.9998 \\
\hline $\mathrm{Pb}$ & 207 & 0.12 & 0.4 & 0.9993 \\
\hline $\mathrm{Li}$ & 7 & 0.0016 & 0.005 & 0.9996 \\
\hline $\mathrm{Mn}$ & 55 & 0.17 & 0.58 & 0.9998 \\
\hline Mo & 95 & 0.012 & 0.04 & 0.9998 \\
\hline $\mathrm{Ni}$ & 60 & 0.009 & 0.03 & 0.9990 \\
\hline $\mathrm{Sr}$ & 88 & 0.011 & 0.04 & 0.9996 \\
\hline $\mathrm{Tl}$ & 205 & 0.0018 & 0.006 & 0.9988 \\
\hline $\mathrm{V}$ & 51 & 1.2 & 4 & 0.9998 \\
\hline $\mathrm{Zn}$ & 64 & 0.2 & 0.8 & 0.9994 \\
\hline $\mathrm{Rh}^{*}$ & 103 & & & \\
\hline
\end{tabular}

Note. Mass, detection limit (LOD), quantification limit (LOQ), and $R^{2}$ of 31 elements detected in the studied samples being LOD and LOQ expressed as $\mu \mathrm{g} / \mathrm{g}$ for all elements. * Internal standard.

sample in glass tubes, which were heated in a boiling water bath for about $40 \mathrm{~min}$. Then, the solutions were poured into plastic tubes and brought up to $25 \mathrm{~mL}$ with purified water. The concentration of the following elements: $\mathrm{Ba}, \mathrm{Bi}, \mathrm{Cd}, \mathrm{Cr}$, $\mathrm{Co}, \mathrm{Cu}, \mathrm{Pb}, \mathrm{Li}, \mathrm{Mn}, \mathrm{Mo}, \mathrm{Ni}, \mathrm{Sr}, \mathrm{Tl}, \mathrm{V}$, and $\mathrm{Zn}, \mathrm{REE}$ (La, Ce, Pr, Nd, Sm, Eu, Gd, Tb, Dy, Ho, Er, Tm, Yb, and Lu), Sc, and $\mathrm{Y}$ were determined. Two multielement stock solutions for the ICP analysis in $5 \% \mathrm{HNO}_{3}$, containing the abovequoted elements at a concentration of $1000 \mathrm{mg} / \mathrm{L}$, were used as stock standards for calibration. $5 \mathrm{~mL}$ volumetric flasks were used in adding the corresponding volume of standard solutions $0.15 \mathrm{~mL}$ of $\mathrm{HNO}_{3}, 0.45 \mathrm{~mL}$ of $\mathrm{HCl}$, and the water necessary to reach the final volume. The concentration of trace elements ranges from $1 \mu \mathrm{g} / \mathrm{L}$ to $600 \mu \mathrm{g} / \mathrm{L}$ except for REE, $\mathrm{Y}$, and Sc that ranges from $1 \mu \mathrm{g} / \mathrm{L}$ to $100 \mu \mathrm{g} / \mathrm{L}$. The measurement accuracy was verified by using the certified reference materials soil NIM GBW07408 and limestone NCS DC60108a. As the internal standard, $50 \mu \mathrm{L}$ of a $1000 \mathrm{mg} / \mathrm{L}$ Rh solution was added to each sample and to each calibration standard. The analyses were performed through an Agilent 7900 inductively coupled plasma mass spectrometer. The measurement conditions that are shown in Table 3 shows the 
ICP-MS parameters employed for the analyses, and Table 4 shows the main analytical features obtained for the measured mass of each considered isotope, including the instrumental detection and quantification limits (LOD and LOQ), and the coefficient of determination $\left(R^{2}\right)$ of the corresponding calibration lines.

2.4. Statistical Data Processing. The PCA models were built by using data obtained from a total of forty-two analysed samples, and the set of data obtained from samples dated to the Roman Imperial period and the Islamic occupation phase obtained previously by Gallello et al. [26]. Major and minor elements and trace elements including REE were employed as variables. This technique was used to explore large geochemical datasets by reducing the number of variables and providing a deep insight into the structure of the variance of the dataset. Data were processed through mean center and autoscale prior to modelling, and the obtained model was cross validated through leave-one-out method.

The PLS-DA model was built employing twenty-two samples as a calibration set: nine samples from the Circus (Los Huertos Street excavation) and samples studied by Gallello et al. [26] including five from the Roman Theatre, TR, built during the Roman Imperial Period and eight samples from Islamic masonries (two samples from the Imperial Forum tabernae, TFI, four samples from the first part of the Islamic Wall, MI, and two from the Torre Central Estudiantes, TCE). Five of these samples (C07, C08, C10b, and two TR samples) were randomly selected as an internal validation set to test the model (data not shown). Sixteen variables were employed (REE, Y, and Sc). Finally, thirtyseven mortar samples dated back to Roman Imperial period, Islamic occupation phase, and also some uncertain samples were included as the test set to predict their class. Data were preprocessed employing mean centering and autoscale, and "leave one out" cross validation method was employed for the evaluation of results. Data analysis was carried out using the PLS Toolbox 6.5 for Eigenvector Research Inc., (Wenatchee, WA, USA) running in Matlab R2014b from MathWorks Inc., (Natick, MA, USA).

\section{Results and Discussion}

3.1. Geochemical Results. The analytical results of major and minor elements as well as trace elements and REE data are reported in the Supplementary Materials (Annexes 1 and 2).

Lime mortar samples from the Railroad Station and from the Circus area buildings have comparable amounts of $\mathrm{Al}_{2} \mathrm{O}_{3}$ and $\mathrm{SiO}_{2}$ which range from 0.44 to $1.05 \mathrm{wt}$. $\%$ and from 11.30 to $26.97 \mathrm{wt}$ \%, respectively, except for samples RS25A $\left(\mathrm{Al}_{2} \mathrm{O}_{3}\right.$ : 3.02 wt.\%; $\mathrm{SiO}_{2}$ : 34.86 wt.\%) and $\mathrm{RS} 11 \mathrm{C}\left(\mathrm{Al}_{2} \mathrm{O}_{3:}\right.$. 5.17 wt.\%; $\mathrm{SiO}_{2}: 36.72$ wt.\%), which are both from the Railroad Station and show particularly high values of these two chemical components. On the contrary, Railroad Station's samples have lower concentration of $\mathrm{CaO}(30 \pm 4$ wt.\%) and higher one of $\mathrm{Fe}(1.3 \pm 0.1 \mathrm{wt} . \%)$ and $\mathrm{Ti}(0.12 \pm 0.01 \mathrm{wt} . \%)$ than Los Huertos Street mortars (CaO: $40 \pm 3$ wt.\%; Fe: $0.99 \pm 0.14$ wt.\%;
TABle 5: Pearson correlation coefficient $(\rho)$ between $\sum$ REE and each measured element for the three groups of mortar.

\begin{tabular}{lccc}
\hline \multirow{2}{*}{ Element } & $\begin{array}{c}\text { Railroad Station } \\
\text { Lime mortars }\end{array}$ & \multicolumn{2}{c}{ Los Huertos Street } \\
& -0.21 & $\mathbf{0 . 5 7}$ & 0.61 \\
$\mathrm{Al}_{2} \mathrm{O}_{3}$ & -0.45 & 0.21 & -0.23 \\
$\mathrm{SiO}_{2}$ & -0.08 & $-\mathbf{0 . 4 3}$ & -0.7 \\
$\mathrm{CaO}$ & 0.18 & 0.3 & $\mathbf{0 . 7 6}$ \\
$\mathrm{Fe}$ & -0.1 & 0.28 & $\mathbf{0 . 8 1}$ \\
$\mathrm{Ti}$ & -0.21 & 0.23 & $\mathbf{0 . 9 5}$ \\
${ }^{209} \mathrm{Bi}$ & 0.41 & 0.03 & -0.09 \\
${ }^{207} \mathrm{~Pb}$ & -0.42 & $\mathbf{0 . 5}$ & $\mathbf{0 . 9 7}$ \\
${ }^{205} \mathrm{Tl}$ & 0.15 & 0.06 & $\mathbf{0 . 8 5}$ \\
${ }^{138} \mathrm{Ba}$ & 0.01 & 0.02 & 0.58 \\
${ }^{111} \mathrm{Cd}$ & -0.04 & -0.29 & $\mathbf{0 . 9 5}$ \\
${ }^{95} \mathrm{Mo}$ & $\mathbf{0 . 5 9}$ & 0.25 & 0.6 \\
${ }^{89} \mathrm{Y}$ & 0 & $-\mathbf{0 . 4 1}$ & $\mathbf{0 . 7 6}$ \\
${ }^{88} \mathrm{Sr}$ & 0.37 & -0.24 & $\mathbf{0 . 9 3}$ \\
${ }^{64} \mathrm{Zn}$ & -0.19 & -0.22 & $\mathbf{0 . 9}$ \\
${ }^{63} \mathrm{Cu}$ & 0.32 & 0.15 & $\mathbf{0 . 8 9}$ \\
${ }^{60} \mathrm{Ni}$ & $\mathbf{0 . 5 1}$ & $\mathbf{0 . 5 1}$ & $\mathbf{0 . 9 6}$ \\
${ }^{59} \mathrm{Co}$ & 0.23 & -0.06 & $\mathbf{0 . 9 4}$ \\
${ }^{55} \mathrm{Mn}$ & 0.48 & $\mathbf{0 . 5 5}$ & $\mathbf{0 . 9 4}$ \\
${ }^{52} \mathrm{Cr}$ & $\mathbf{0 . 5 6}$ & 0.24 & $\mathbf{0 . 8 8}$ \\
${ }^{51} \mathrm{~V}$ & 0.49 & $\mathbf{0 . 7 5}$ & $\mathbf{0 . 7 1}$ \\
${ }^{45} \mathrm{Sc}$ & 0.19 & 0.35 & $\mathbf{0 . 8 2}$ \\
${ }^{7} \mathrm{Li}$ & ${ }^{\mathrm{Li}}$ & &
\end{tabular}

Note. Statistically significant values of $\rho$ are given in bold $(p=0.05)$.

Ti: $0.08 \pm 0.02$ wt.\%). The samples of earth mortars from Room 1 (R1a, R1b, and R1c) and Room 2 (R2a, R2b, and R2d) show the lowest values of $\mathrm{CaO}(15.3 \pm 1.1 \mathrm{wt} . \%)$ and the highest ones of $\mathrm{Al}_{2} \mathrm{O}_{3}\left(10.9 \pm 1.1\right.$ wt.\%), $\mathrm{SiO}_{2}(37.8 \pm 1.7$ wt.\%), $\mathrm{Fe}(2.4 \pm 0.3 \mathrm{wt} . \%)$, and $\mathrm{Ti}(0.25 \pm 0.02 \mathrm{wt} . \%)$.

The lime mortar samples from Los Huertos Street and from the Railroad Station have comparable concentrations in almost all the measured trace elements. In particular, it is worth noticing that the two groups of samples show similar REE total amounts ( $\sum$ REE) (Los Huertos Street: $20 \pm 4 \mu \mathrm{g} / \mathrm{g}$; Railroad Station: $20 \pm 2 \mu \mathrm{g} / \mathrm{g}$ ) and Sc concentrations (Los Huertos Street: $1.1 \pm 0.3 \mu \mathrm{g} / \mathrm{g}$; Railroad Station: $1.1 \pm 0.1 \mu \mathrm{g} / \mathrm{g}$ ), while samples from Los Huertos Street have a slightly higher concentration of $\mathrm{Y}$ than the ones from the Railroad Station excavation (4.1 \pm $0.8 \mu \mathrm{g} / \mathrm{g}$ and $3.5 \pm 0.4 \mu \mathrm{g} / \mathrm{g}$ resp.). Concerning the earth mortars from Room 1 and Room 2, they have comparable contents of REE, Y, and Sc. REE total amounts go from $37 \mu \mathrm{g} / \mathrm{g}$ to $53 \mu \mathrm{g} / \mathrm{g}$, and $\mathrm{Y}$ and Sc range from $5 \mu \mathrm{g} / \mathrm{g}$ to $10 \mu \mathrm{g} / \mathrm{g}$ and from $2 \mu \mathrm{g} / \mathrm{g}$ to $3 \mu \mathrm{g} / \mathrm{g}$, respectively.

To give a deep insight into the mechanisms that influence the amount of REE in the mortar samples, it is interesting to look at the correlation among the REE and analysed elements for each group of mortars. Table 5 shows the Pearson correlation coefficient $(\rho)$ considering as variables REE total amounts and the indicated elements for each group of mortars considered separately (see Supplementary Materials Annex 2). Only statistically significant data were taken into account given $p=0.05$. REE concentration of Los Huertos Street lime mortar samples show positive correlations, as well as for Sc $(\rho=0.75)$, which has a chemical behaviour similar to lanthanides, with $\mathrm{Al}_{2} \mathrm{O}_{3}(\rho=0.57), \mathrm{Tl}(\rho=0.50)$, 


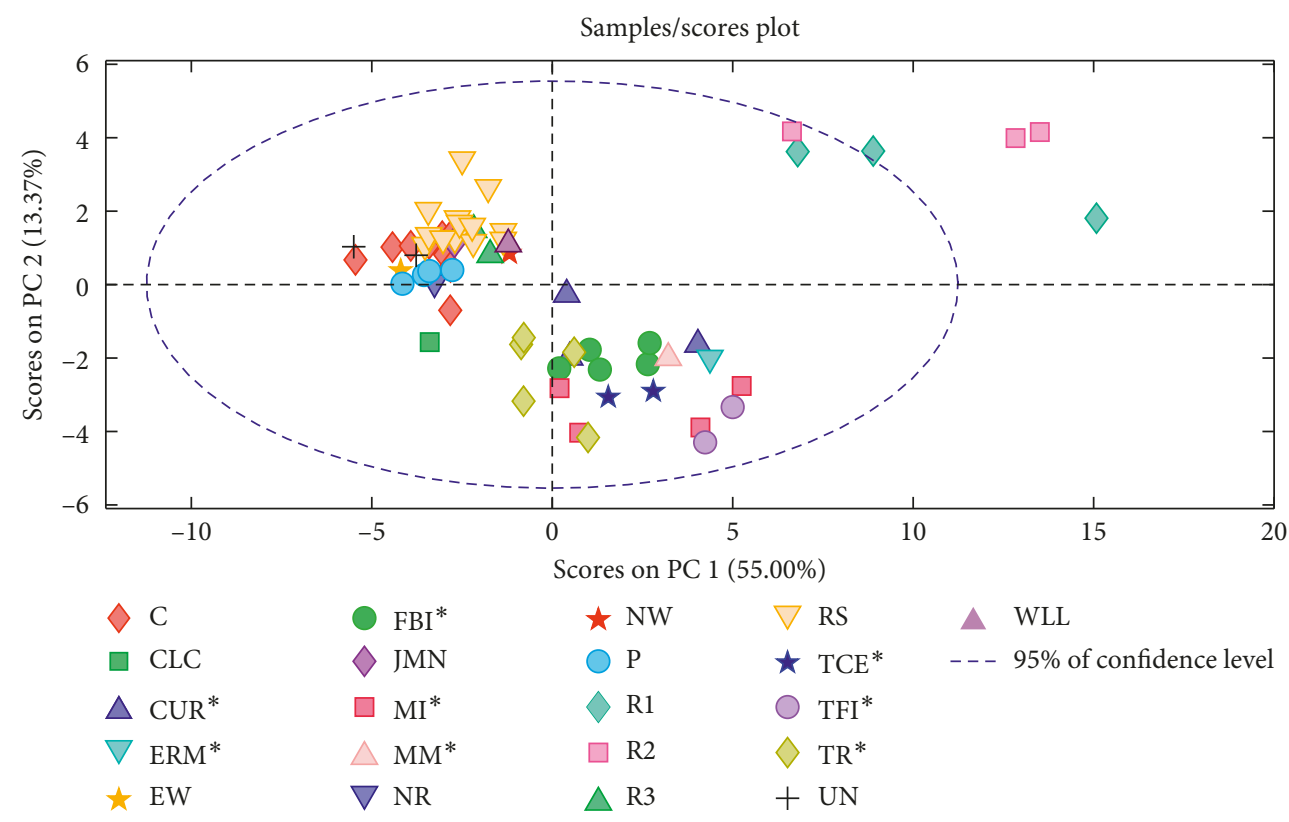

(a)

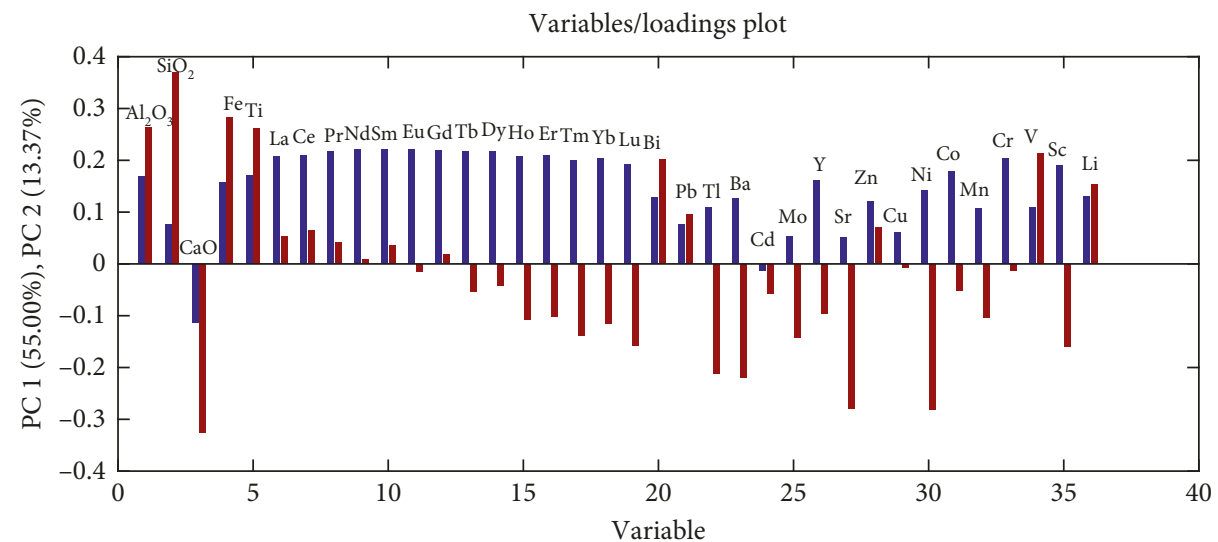

PC $1(55.00 \%)$

PC $2(13.37 \%)$

(b)

Figure 2: PCA study employing all the measured element concentrations. Scores (a) and loadings (b) plot of PC1 and PC2. The samples marked with a star $\left({ }^{*}\right)$ are related to Sagunto Castle buildings [17]. ERM = Hermitage; FBI = Imperial Basilica; FRW = Wester Republican Forum; MI = Islamic Wall (1st section); MII = Islamic Wall (2nd section); MM= Modern Wall; SMR = Republican Wall; TCE = Torre Central Estudiantes; TFI = Imperial Forum tabernae; TMP = Republican Diana's Temple; TR = Roman Theatre.

Co $(\rho=0.51)$, and $\operatorname{Cr}(\rho=0.55)$ and negative correlations with $\mathrm{Ca}(\rho=-0.43)$ and $\mathrm{Sr}(\rho=-0.41)$, which suggests that the major contribution to the amount of REE comes from limestone clay impurities or from aluminosilicates and silicate rock clasts present in the aggregate fraction [27]. Concerning the lime mortar samples from the Railroad Station excavation, significant correlations were not detected among major elements and REE. However, significant positive correlations were found with $\mathrm{Y}(\rho=0.59)$, Co $(\rho=0.51)$ and $\mathrm{V}(\rho=0.56)$. As regards earth mortars (R1 and R2) from Los Huertos Street, in this case, the REE total amount has high positive correlations with most of the trace elements (for $\mathrm{Bi}, \mathrm{Tl}, \mathrm{Ba}, \mathrm{Mo}, \mathrm{Sr}, \mathrm{Zn}, \mathrm{Cu}, \mathrm{Ni}, \mathrm{Co}, \mathrm{Mn}, \mathrm{Cr}, \mathrm{V}$, Sc, and Li, $\rho$ goes from 0.71 to 0.97 ) and, among the major elements, with Fe $(\rho=0.76)$ and Ti $(\rho=0.81)$, suggesting that the major contribution in lanthanides comes probably from clay fraction, other silicate minerals, and silicate rock clasts.

\subsection{Chemometrics for Construction Phase Discrimination.} The identification of the construction phases of the buildings was conducted by comparing the mortars from the Railroad Station and Los Huertos Street to the ones from Sagunto Castle published by Gallello et al. [26], and whose construction periods were retraced in the same work. In particular, this previous study was focused on REE concentrations due to their proved effectiveness in 


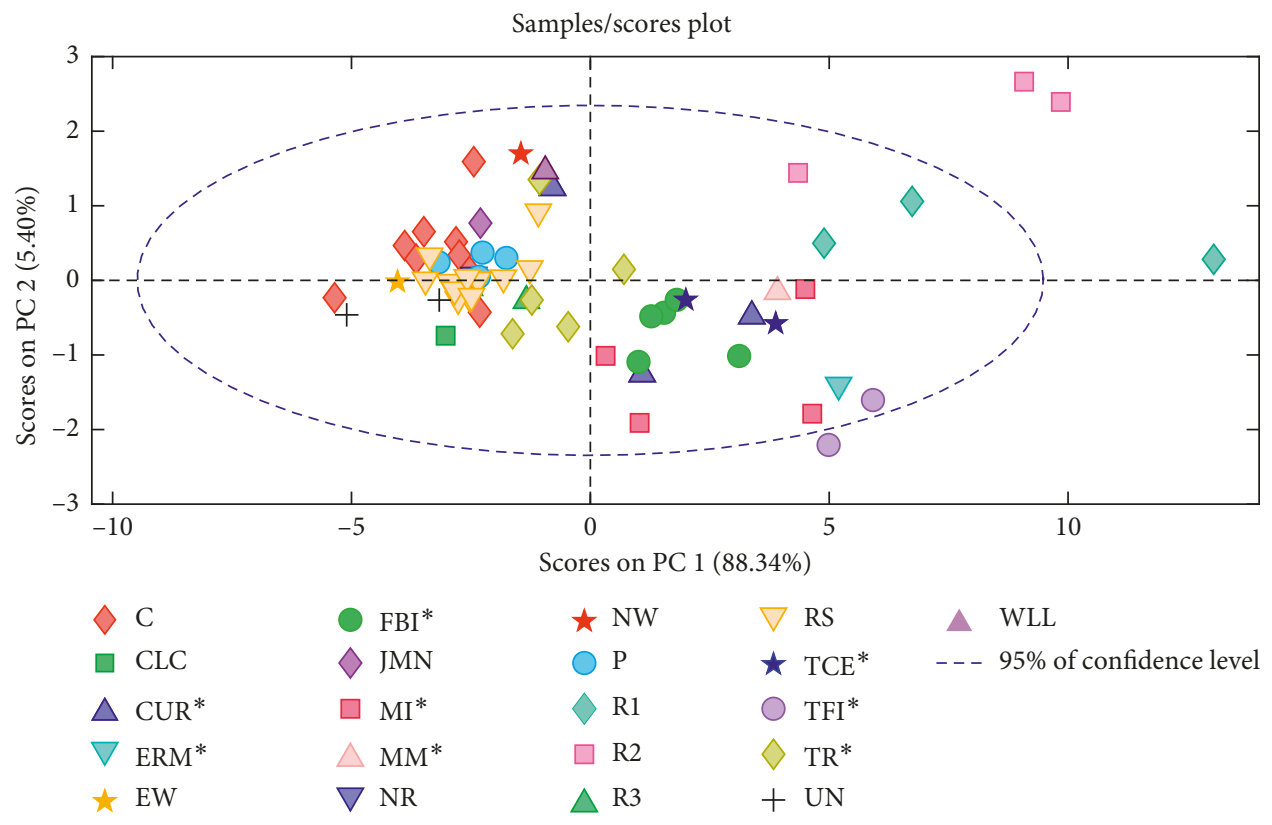

(a)

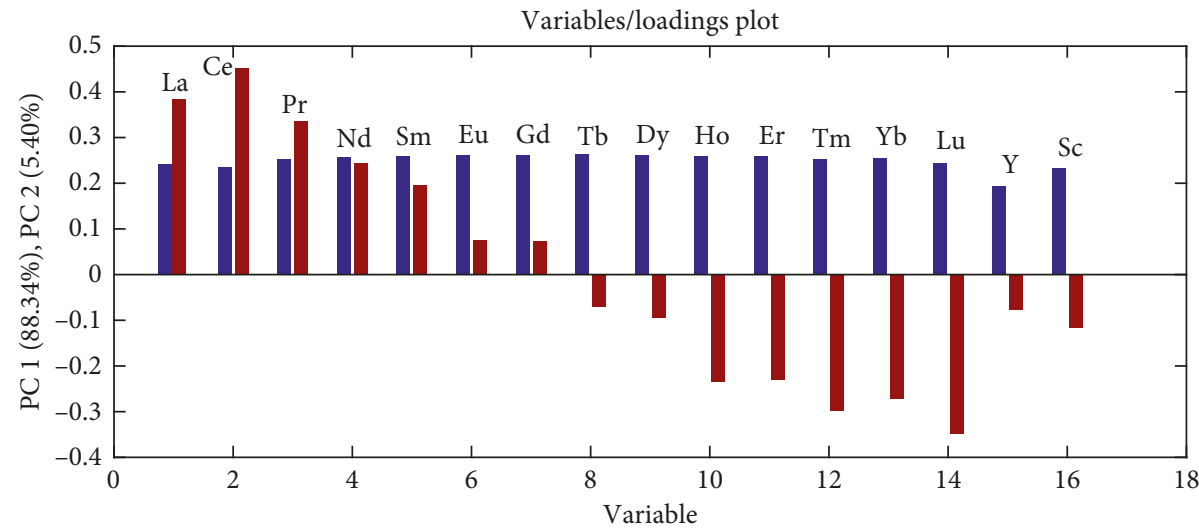

PC $1(88.34 \%)$

PC 2 (5.40\%)

(b)

Figure 3: PCA study employing only REE, Y, and Sc concentrations. Scores (a) and loadings (b) plot of PC1 and PC2. The legend for Sagunto Castle samples' classes $\left({ }^{*}\right)$ is indicated in Figure 2.

archaeometric studies about provenance and raw materials of lithic and lithoid archaeological artifacts [28-30].

To compare the samples from the excavations to the Imperial and Islamic mortars from Sagunto Castle [26], the principal component analysis (PCA) was carried using all variables (i.e., elements) (Figure 2). Figure 2(b) shows the contribution of the variables in PC1 $(55.00 \%$ of samples' variance) and PC2 (13.37\% of samples' variance). Figure 2(a) shows the position of each sample in a diagram where the $x$-axis corresponds to PC1 coordinates and $y$-axis to PC2. Most of the samples of Los Huertos Street and all Railroad Station are grouped together in the left side of the plot, while the samples dated back both to Imperial Roman period and Islamic period from de Castle are grouped in the right part of the graph. The samples of earth mortars from Room 1 (R1a, R1b, and R1c) and Room 2 (R2a, R2b, and R2d) of Los Huertos Street are plotted in the upper right side of the diagram, at the limit of the confidence interval or out of it.

In Figure 3(b), the contribution of the REE employed as variables is shown. PC1 explains $88.34 \%$ of the data variance and PC2 explains 5.40\%. Lime mortar samples from Los Huertos Street and all Railroad Station excavations are grouped with the mortars from the Roman Theatre (TR) (Figure 3(a)), suggesting that the dating to the Roman Imperial period was also confirmed by the archaeological data while the earth mortar samples are plotted in PC1 and PC2 positive directions. Finally, a separation between mortars from Imperial Period (PC1 negative direction), and mortars from the Islamic Period, located in the left lower area of PC can be appreciated.

Since the discrimination of lime mortars from Roman Imperial and Islamic buildings seems to be the most 


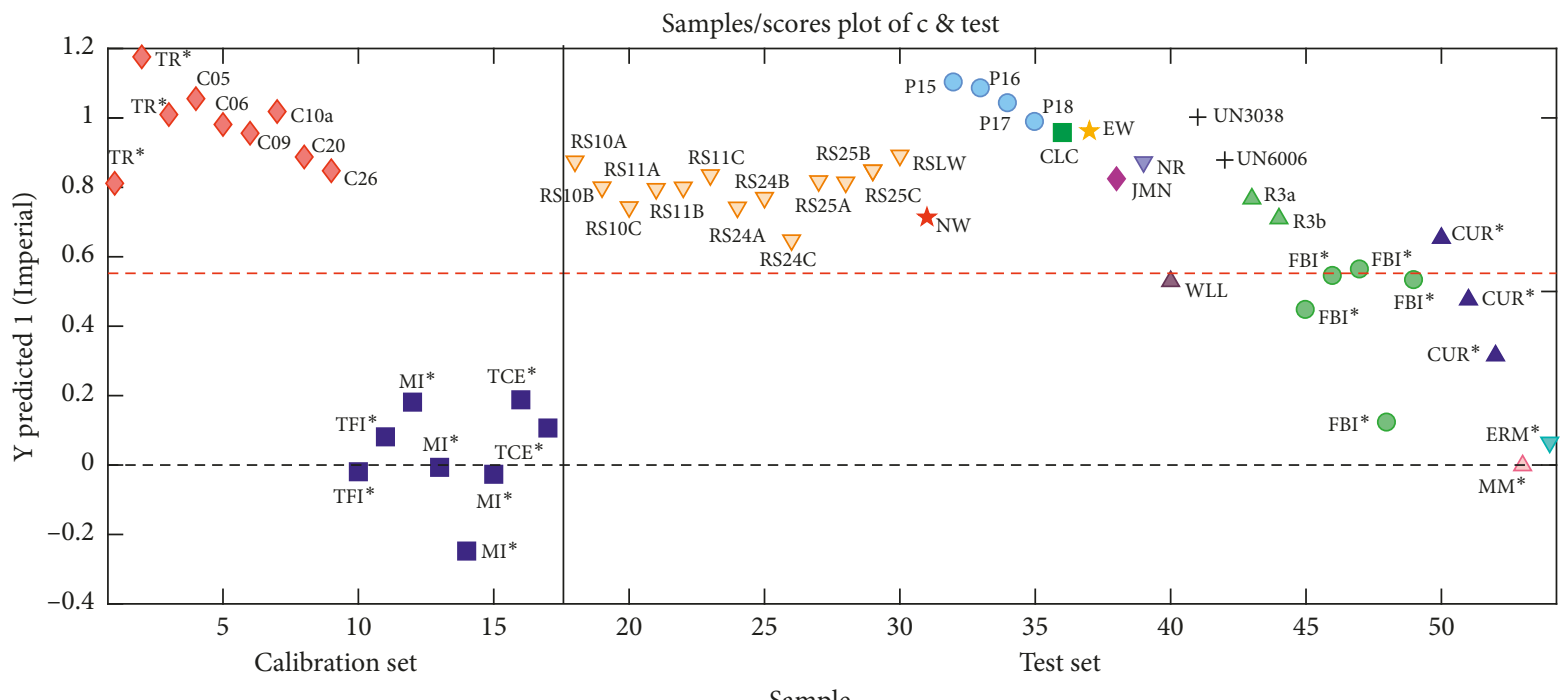

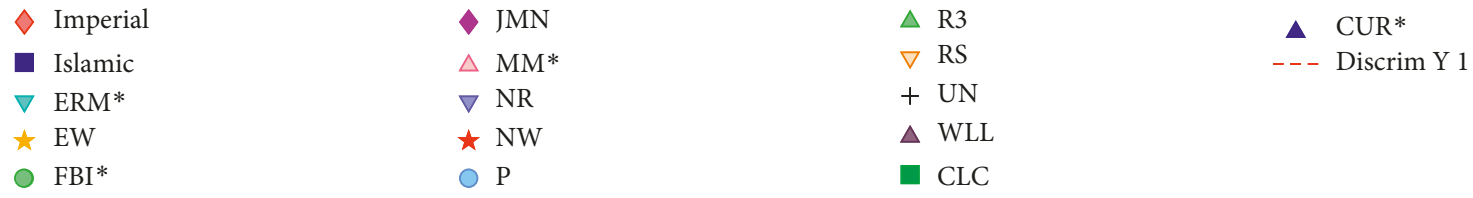

(a)

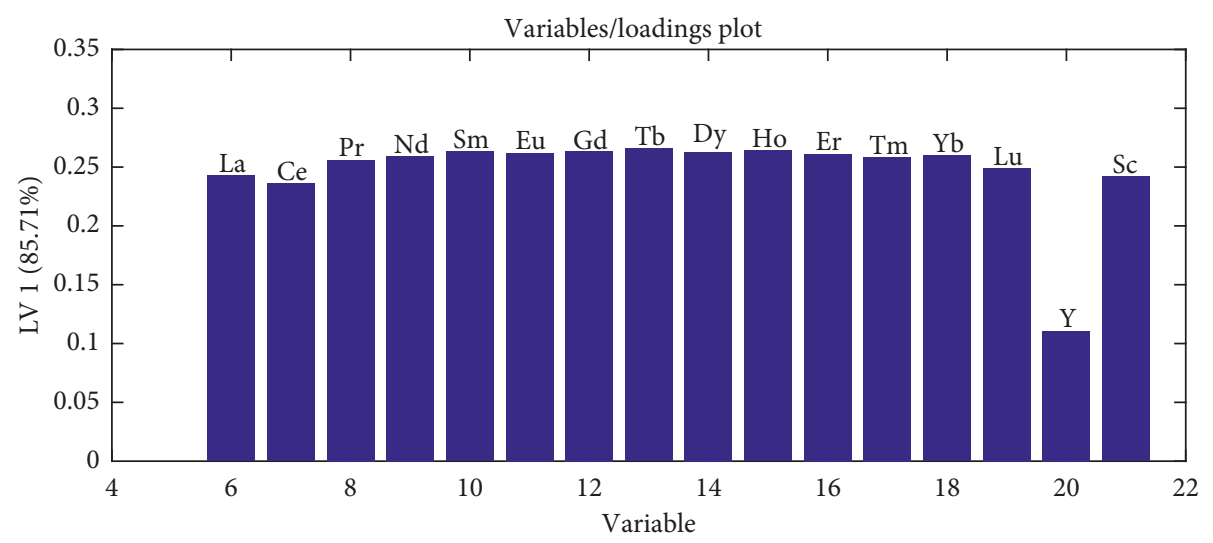

(b)

Figure 4: PLS-DA results. (a) Calibration set and predicted class membership of the other samples. (b) VIP scores of the PLS-DA model. The legend for Sagunto Castle classes $\left({ }^{*}\right)$ is indicated in Figure 2.

problematic issue, the principal least squares discriminant analysis (PLS-DA) was employed to build a statistical model to classify uncertain samples. The calibration set and validation set were established by using samples from buildings and masonries that were previously classified by Gallello et al. [26] and by archaeological data as Roman Imperial (C and TR) or as Islamic (MII, TFI, and TCE) (Figure 4(a)). Figure 4(b) shows the contribution of each variable to the model. As it can be seen, the model clearly separates between mortars of the two different construction phases. Subsequently, the model was applied to a test set composed of uncertain Roman Imperial period or Islamic mortars (Figure 4(a)). The PLS-DA results confirmed that all the mortars from Los Huertos Street and Railroad Station are classified as Roman Imperial period materials except for sample WLL that has been classified as Islamic, which is coherent with the archaeological data that confirm the occupation of the area during the Islamic phase. As observed, on the contrary of Los Huertos Street, in Railroad Station samples, major elements are not correlated with REE (Table 5), and this could suggest that the mortars were made in a different way or this is an indicator of recycling building materials, and, according to the archaeological wall stratigraphy interpretation, the Railroad Station structures could be dated after the Imperial period. Thus, maybe they were built during the Late Roman Age. On the contrary, one mortar sample from the Basilica of the Imperial Forum (FBI $\mathrm{SC}$ ) and one mortar from the Curia testify the presence of 
both Roman Imperial masonries and Islamic reworks in Roman buildings due to the heavy reemployment of the Imperial Forum area during the Islamic occupation [26].

The use of REE, Y, and Sc as variables has shown their high effectiveness in the discrimination of different kinds of mortars to retrace the construction history of archaeological sites and monuments. The comparison among mortars coming from different archaeological excavations and monuments of the same geographical area seems to be a very viable method to solve chronological issues related to the construction phases of both structures unearthed during archaeological excavations and historical complexes.

\section{Conclusion}

The study of the historic mortars from two archaeological excavations (i.e., Los Huertos Street and Railroad Station) located in the city of Sagunto permitted us to solve issues that had remained unanswered in the previous studies on these building materials.

The use of multivariate statistics employing REE as variables allowed us to classify the lime mortars belonging to the Imperial Roman period, in line with the archaeological data; however, the case of the Railroad Station structure needs deeper studies to confirm the chronology as Imperial Roman or Late Roman Ages. Also, it was possible to establish the chronological phase of some masonries of Sagunto Castle whose period of construction was uncertain and that can be attributed to the phase of the Islamic occupation or to the Roman Imperial period. The PLS-DA model was helpful to discriminate among mortars of uncertain attribution and that can be useful for possible future studies in Sagunto area.

The correlation among REE and major/minor and trace elements shows that the mechanisms that allowed REE to be discriminating parameters between Sagunto mortars belonging to different periods are related to chemical weathering processes involving limestone clay impurities, aluminosilicates, and silicate rock clasts present in the aggregate fraction. Therefore, further works need to be developed focusing the understanding of the chemical processes that are influencing the REE distributions.

Summarizing, the present study has confirmed the effectiveness of REE data in building materials as markers of different construction phases and has proved the usefulness of the application of the ancient mortar analysis on a geographical scale wider than a single archaeological excavation or monuments.

\section{Data Availability}

The data used to support the findings of this study are included within the article and supplementary materials.

\section{Conflicts of Interest}

The authors declare that there are no conflicts of interest with any institution or funding body.

\section{Acknowledgments}

The authors acknowledge also the analytical support of the Central Service for Experimental Research (SCSIE) of the University of Valencia, and of Dr. Laredo Ortíz and Dr. Soriano Vega. The authors would like to thank all the archaeologists working in Railroad Station and Los Huertos Street excavations, who have contributed the realization of this study and especially the Archaeologist at the Sagunto's Council, Ms. Carla Flors. Authors acknowledge the financial support of Generalitat Valenciana (PROMETEO project II/2014/077) and Ministerio de Economia y CompetitividadFeder (Project CTQ 2014-52841-P and Project CTQ 201238635). Gianni Gallello acknowledges the financial support of the European Commission (Project H2020-MSCA-IF2015-704709-MATRIX).

\section{Supplementary Materials}

Annex 1: concentrations of the measured major and minor elements obtained by pED-XRF. Annex 2: trace elements and REE results obtained by ICP-MS. (Supplementary Materials)

\section{References}

[1] A. Moropoulou, A. Bakolas, and K. Bisbikou, "Investigation of the technology of historic mortars," Journal of Cultural Heritage, vol. 1, no. 1, pp. 45-58, 2000.

[2] M. Theodoridou, I. Ioannou, and M. Philokyprou, "New evidence of early use of artificial pozzolanic material in mortars," Journal of Archaeological Science, vol. 40, no. 8, pp. 3263-3269, 2013.

[3] M. Franzini, L. Leoni, M. Lezzerini, and F. Sartori, "The mortar of the "Leaning Tower" of Pisa: the product of a medieval technique for preparing high-strength mortars," European Journal of Mineralogy, vol. 12, no. 6, pp. 1151-1163, 2000.

[4] F. Marra, A. Danti, and M. Gaeta, "The volcanic aggregate of ancient Roman mortars from the Capitoline Hill: petrographic criteria for identification of Rome's "pozzolans" and historical implications," Journal of Volcanology and Geothermal Research, vol. 308, pp. 113-126, 2015.

[5] M. Lezzerini, M. Ramacciotti, F. Cantini et al., "Archaeometric study of natural hydraulic mortars: the case of the Late Roman Villa dell'Oratorio (Florence, Italy)," Archaeological and Anthropological Science, vol. 9, no. 4, pp. 603-615, 2017.

[6] M. Lezzerini, S. Pagnotta, S. Raneri et al., "Examining the reactivity of volcanic ash in ancient mortars by using a micro-chemical approach," Mediterranean Archaeology and Archaeometry, In press.

[7] S. Columbu and A. M. Garau, "Mineralogical, petrographic and chemical analysis of geomaterials used in the mortars of Roman Nora theatre (south Sardinia, Italy)," Italian Journal of Geosciences, vol. 136, no. 2, pp. 238-262, 2017.

[8] S. Columbu, "Petrographic and geochemical investigations on the volcanic rocks used in the Punic-Roman archaeological site of Nora (Sardinia, Italy)," Earth Environmental Sciences, In press.

[9] J. Elsen, A. Brutsaert, M. Deckers, and R. Brulet, "Microscopical study of ancient mortars from Tournai (Belgium)," 
Materials Characterization, vol. 53, no. 2-4, pp. 289-294, 2004.

[10] C. Borges, A. Santos Silva, and R. Veiga, "Durability of ancient lime mortars in humid environment," Construction and Building Materials, vol. 66, pp. 606-620, 2014.

[11] M. Lezzerini, S. Legnaioli, G. Lorenzetti, V. Palleschi, and M. Tamponi, "Characterization of historical mortars from the bell tower of St. Nicholas church (Pisa, Italy)," Construction and Building Materials, vol. 69, pp. 203-214, 2014.

[12] D. Miriello, F. Antonelli, C. Apollaro et al., "New data about the ancient mortars from the archaeological site of Kyme (Turkey): compositional characterization," Minerals Engineering, vol. 84, pp. 497-517, 2015.

[13] S. Columbu, F. Sitzia, and G. Ennas, "The ancient pozzolanic mortars and concretes of Heliocaminus baths in Hadrian's Villa (Tivoli, Italy)," Archaeological and Anthropological Sciences, vol. 9, no. 4, pp. 523-553, 2017.

[14] F. Carò, M. P. Riccardi, and M. T. Mazzilli Savini, "Characterization of plasters and mortars as a tool in archaeological studies: the case of Lardirago Castle in Pavia, Northern Italy," Archaeometry, vol. 50, no. 1, pp. 85-100, 2008.

[15] E. Arizio, R. Piazza, W. R. L. Cairns, L. Apollonia, and A. Botteon, "Statistical analysis on ancient mortars: a case study of the Balivi Tower in Aosta (Italy)," Construction and Building Materials, vol. 47, pp. 1309-1316, 2013.

[16] C. Corti, L. Ramazzi, R. Bugini et al., "Thermal analysis and archaeological chronology: the ancient mortars of the site of Baradello (Como, Italy)," Thermochimica Acta, vol. 572, pp. 71-84, 2013.

[17] F. Marra, E. D’Ambrosio, M. Gaeta, and M. Mattei, "Petrochemical identification and insights on chronological employment of the volcanic aggregates used in ancient Roman mortars," Archaeometry, vol. 58, no. 2, pp. 177-200, 2016.

[18] A. M. Conte, L. Corda, D. Esposito, and E. Giorgi, "Characterization of mortars from the medieval Abbey of Cerrate (southern Italy)," Journal of Archaeological Science: Reports, vol. 12, pp. 463-479, 2017.

[19] S. Columbu, "Provenance and alteration of pyroclastic rocks from the Romanesque Churches of Logudoro (north Sardinia, Italy) using a petrographic and geochemical statistical approach," Applied Physics A, vol. 123, p. 165, 2017.

[20] S. Columbu, F. Sitzia, and G. Verdiani, "Contribution of petrophysical analysis and 3D digital survey in the archaeometric investigations of the Emperor Hadrian's Baths (Tivoli, Italy)," Rendiconti Lincei, vol. 26, no. 4, pp. 455-474, 2015.

[21] I. Papayianni and M. Stefanidou, "Durability aspects of ancient mortars of the archaeological site of Olynthos," Journal of Cultural Heritage, vol. 8, no. 2, pp. 193-196, 2007.

[22] I. Papayianni, V. Pachta, and M. Stefanidou, "Analysis of ancient mortars and design of compatible repair mortars: the case study of Odeion of the archaeological site of Dion," Construction and Building Materials, vol. 40, pp. 84-92, 2013.

[23] M. Lezzerini, F. Antonelli, S. Columbu et al., "The documentation and conservation of the cultural heritage: 3D laser scanning and GIS techniques for thematic mapping of the stonework of the façade of St. Nicholas Church (Pisa, Italy)," International Journal of Architectural Heritage: Conservation, Analysis, and Restoration, vol. 10, no. 1, pp. 9-19, 2016.

[24] S. Columbu, M. Palomba, F. Sitzia, and M. R. Murgia, "Geochemical and mineral-petrographic studies of stones and mortars from the Romanesque Saccargia Basilica (Sardinia, Italy) to define their origin and alteration," Italian Journal of Geosciences, vol. 137, no. 3, pp. 1-27, 2018.
[25] P. P. Ripollés, Opulentissima Saguntum, Bancaja, Sagunto, Spain, 2004.

[26] G. Gallello, M. Ramacciotti, M. Lezzerini et al., "Indirect chronology method employing rare earth elements to identify Sagunto Castle mortar construction periods," Microchemical Journal, vol. 132, pp. 251-261, 2017.

[27] H. R. Rollins, Using Geochemical Data: Evaluation, Presentation, Interpretation, Pearson Education Limited, London, UK, 1993.

[28] G. Gallello, T. Orozco, A. Pastor, M. de la Guardia, and J. Bernabeu, "Regional provenance of dolerite prehistoric objects through mineral analysis," Microchemical Journal, vol. 124, pp. 167-174, 2016.

[29] A. Hein, P. M. Day, P. S. Quinn, and V. Kilikoglou, "The geochemical diversity of Neogene clay deposits in Crete and its implications for provenance studies of Minoan pottery," Archaeometry, vol. 46, no. 3, pp. 357-384, 2004.

[30] S. Cagno, M. Mendera, T. Jeffries, and K. Janssens, "Raw materials for post-medieval Tuscan glassmaking: new insight from LA-ICP-MS analyses," Journal of Archaeological Science, vol. 37, no. 12, pp. 3030-3036, 2010. 

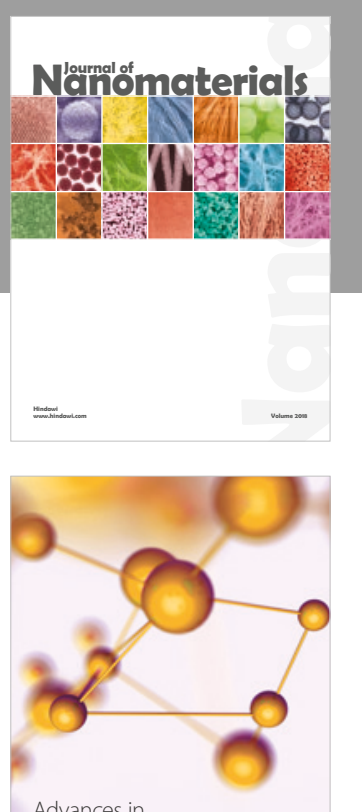

Physical Chemistry
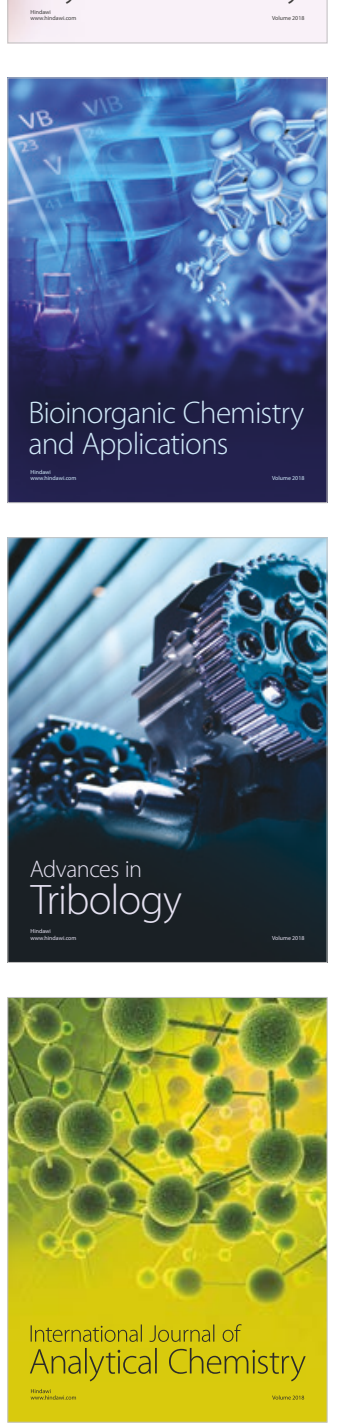

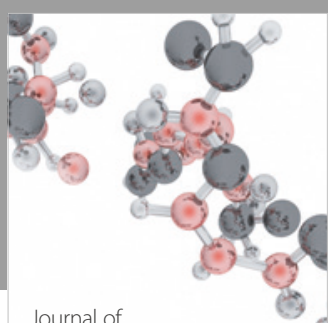

Analytical Methods

in Chemistry

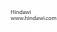

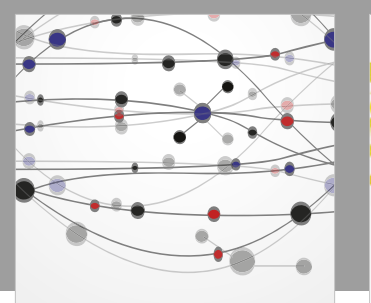

The Scientific World Journal

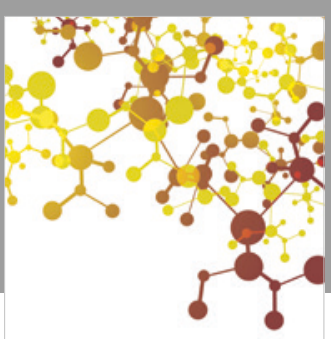

Journal of

Applied Chemistry
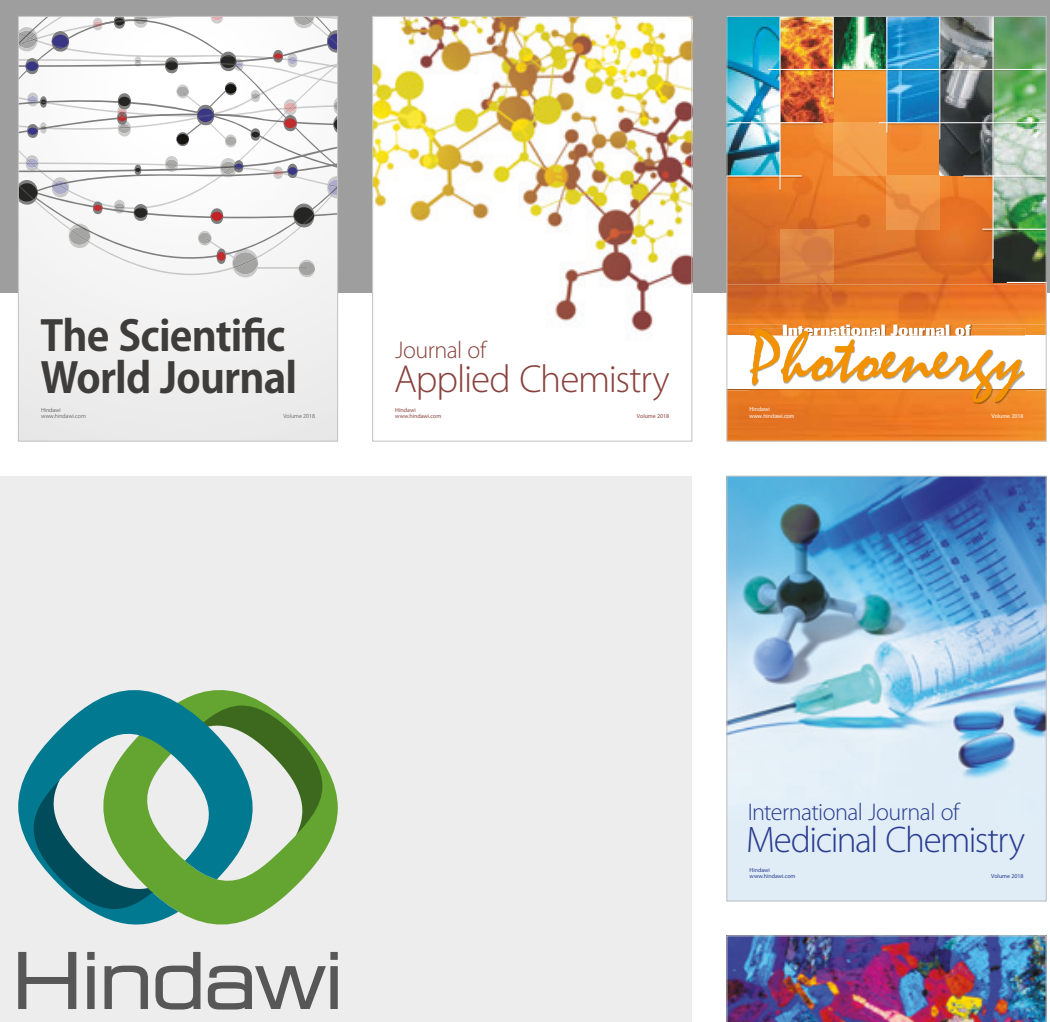

Submit your manuscripts at

www.hindawi.com
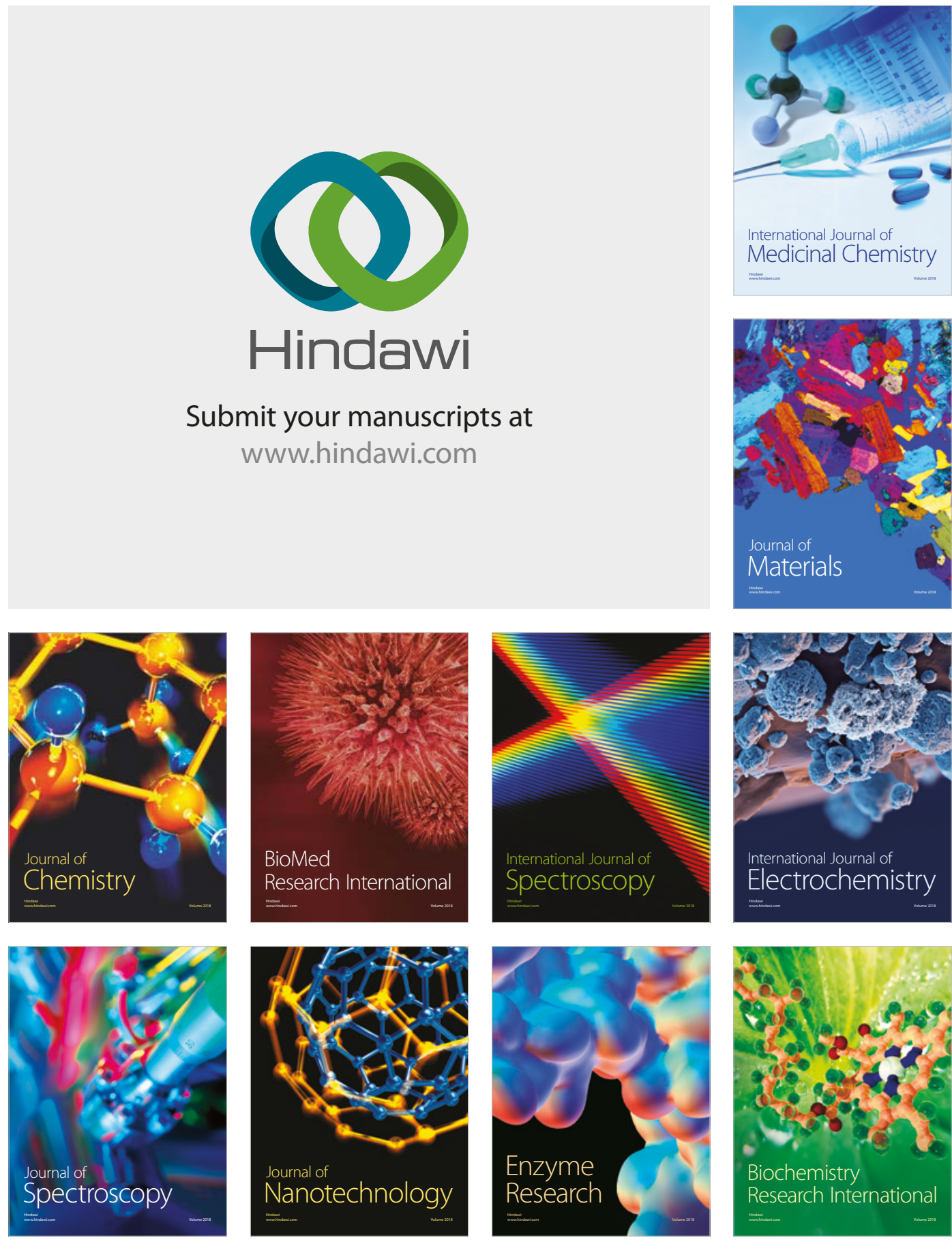
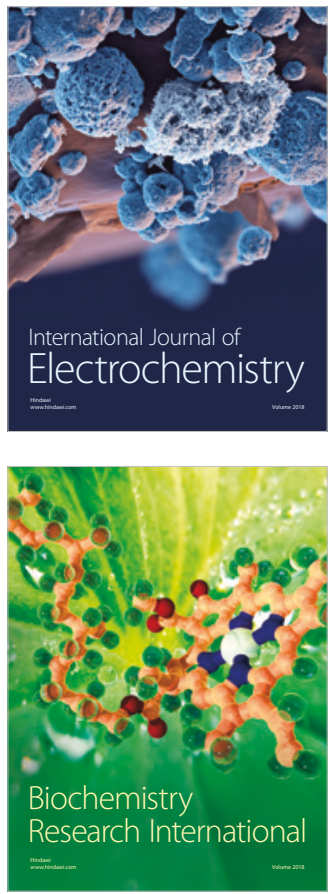